\title{
A game theoretic model of the Northwestern European electricity market - market power and the environment
}

\author{
Wietze Lise ${ }^{\mathrm{a}, \mathrm{b}, *}$, Vincent Linderhof ${ }^{\mathrm{b}}$, Onno Kuik ${ }^{\mathrm{b}}$, Claudia Kemfert ${ }^{\mathrm{c}}$, Robert Östling ${ }^{\mathrm{d}}$, \\ Thomas Heinzow ${ }^{\mathrm{e}}$
}

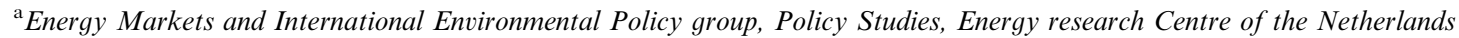 \\ ${ }^{\mathrm{b}}$ Institute for Environmental Studies, Faculty of Earth and Life Sciences, Vrije Universiteit, Amsterdam, The Netherlands \\ ${ }^{\mathrm{c}}$ German Institute for Economic Research, Department Energy, Transportation and Environment, Humboldt University, Berlin, Germany \\ ${ }^{\mathrm{d}}$ Department of Economics, Stockholm School of Economics, Stockholm, Sweden \\ ${ }^{\mathrm{e}}$ Hamburg University, Hamburg, Germany
}

Available online 30 April 2005

\begin{abstract}
This paper develops a static computational game theoretic model. Illustrative results for the liberalising European electricity market are given to demonstrate the type of economic and environmental results that can be generated with the model. The model is empirically calibrated to eight Northwestern European countries, namely Belgium, Denmark, Finland, France, Germany, The Netherlands, Norway, and Sweden. Different market structures are compared, depending on the ability of firms to exercise market power, ranging from perfect competition without market power to strategic competition where large firms exercise market power. In addition, a market power reduction policy is studied where the near-monopolies in France and Belgium are demerged into smaller firms. To analyse environmental impacts, a fixed greenhouse gas emission reduction target is introduced under different market structures. The results indicate that the effects of liberalisation depend on the resulting market structure, but that a reduction in market power of large producers may be beneficial for both the consumer (i.e. lower prices) and the environment (i.e. lower greenhouse gas permit price and lower acidifying and smog emissions).
\end{abstract}

(C) 2005 Elsevier Ltd. All rights reserved.

Jel classification: C7; D2; Q4; R3

Keywords: Electricity market; Liberalisation; Market power; Game theory; Environmental impacts; Northwestern Europe

\section{Introduction}

By the year 2007 all EU-15 member countries will have liberalised their electricity markets if they live up to their commitments according to EU Directive 96/92/EC. The European electricity market is currently in the midst of a drastic transformation from monopolistic, national and state-owned producers to a market with competing, private and often multinational firms. Although the

\footnotetext{
${ }^{*}$ Corresponding author. Energy research Centre of the Netherlands (ECN), Badhuisweg 3, $1031 \mathrm{CM}$ Amsterdam, The Netherlands. Tel.: + 31224564511 ; fax: + 31224564480 .

E-mail address: lise@ecn.nl (W. Lise).
}

speed and current state of this process vary widely across Europe, this process will definitely affect the structure of the European electricity market. In the present European electricity market we can see a whole range of different structures from a near-monopoly in France to highly competitive markets in the Nordic countries.

The effects of liberalisation on market structure are illustrated by the development in Germany. Following liberalisation, the initial 30 relatively small electricity producers were merged into four large producers in only a few years time. These firms probably have some market power on the German market, but they also face competition from neighbouring countries. The extent of 
international competition is limited by the transmission capacities between countries, but is also affected by the market structure in these neighbouring countries.

Yet little is known about the environmental consequences of liberalisation. The main goal of liberalising the electricity market is to achieve more cost efficient production and lower electricity prices. On the one hand, this may be beneficial for the environment since more cost efficient production may reduce the burden on the environment, while, on the other hand, lower market prices imply higher electricity demand that increase the burden on the environment. Moreover, in the near future, new developments, such as the implementation of the EU $\mathrm{CO}_{2}$ emission trading system in 2005, may have major environmental impacts (Sijm, 2004).

To study this complex process, we develop a static computational game theoretic model, which can study economic and environmental consequences of different market structures. The model allows us to answer questions about the wholesale price and demand for electricity, profits of electricity producers, and emissions to the environment. The model covers eight Northwestern European countries, namely Belgium, Denmark, Finland, France, Germany, the Netherlands, Norway and Sweden, which we for simplicity refer to as "EU8". These countries together constitute a substantial part of the European electricity market. Fig. 1 shows the distribution of total electricity production capacity and demand across these eight countries, which amounted to a production capacity of $259 \mathrm{GW}$ and an annual demand of $1423 \mathrm{TWh}$ in the year 2000.

The model captures different market structures depending on firm's abilities to exercise market power. The two extreme cases are, on the one hand, perfect (or price) competition where firms do not exercise market power and, on the other hand, strategic (or quantity) competition where firms fully exercise market power. In between these two extreme market structures there are several possible oligopolistic market structures where firms exercise market power to a more limited extent. ${ }^{2}$

To study a policy that aims at reducing market power, we also consider a scenario where the two nearmonopoly producers in France and Belgium are split into smaller firms. We have chosen for the French and Belgian markets, since there are already pressures on these markets to reduce market power by virtual capacity auctions. Furthermore, it is quite likely that a reduction of market concentration is going to be enforced in the near future (Becker et al., 2004).

\footnotetext{
${ }^{1}$ Although this name suggests that Norway is an EU member, we are well aware of the fact that this is not the case.

${ }^{2}$ For instance, models with supply function equilibrium, where the firms do not fully exercise market power. Solving such models is computationally more demanding.
}

To study possible environmental consequences of liberalisation, we compare a scenario with environmental constraints to an unconstrained case. The environmental constraint consists of a greenhouse gas emission reduction target of $30 \%$ for the EU8 with respect to the 2000 levels of emission, although an overall reduction of $2.3 \%$ with respect to 2000 levels of emission for the EU8 economy as a whole is sufficient to meet the target of the Kyoto protocol. We have chosen an above-average reduction target in the electricity sector in these scenarios because the potential for reduction is much higher than in other sectors.

It is of interest to compare the outcomes of different market structures for the fixed reduction target, since it is likely that competition is imperfect in a liberalised electricity market, where large firms can increase profits by exercising market power. In the fixed target case the required permit price differs depending on the market structure.

The electricity MarkEt liberalisation in Europe (EMELIE) model, which is used in this paper, is an extended version of the original model applied to the German electricity market in Kemfert (1999), Kemfert and Tol (2000), Kemfert et al. (2002) and Lise et al. (2003). The original model is extended in three major ways. First of all, the model considers eight countries instead of Germany alone, and trade of electricity is possible among countries. Secondly, environmental constraints can be imposed via emission factors of the generation technologies used for production. Finally, the model distinguishes between two load periods, peak load (hours with particularly high demands for electricity) and base load (hours with average demands for electricity). In the model, peak and base load are considered as two separate electricity markets. ${ }^{3}$ The combination of these features makes the EMELIE model unique in comparison with other electricity market models (i.e. Amundsen and Bergman, 2002; Bigano and Proost, 2002; Hobbs and Rijkers, 2004a, b; Newberry et al., 2003; Pineau and Murto, 2003).

To study the robustness of the model, a number of sensitivity analyses have been undertaken with the EMELIE model, which are reported in Lise and Linderhof (2004). The overall effects were largely in the expected directions indicating that the model is quite robust against perturbations. The details at the country level could, however, deviate from the overall pattern,

\footnotetext{
${ }^{3}$ For this paper, we apply a static year-based model of EMELIE; an hourly-based model version of EMELIE is used in Grohnheit (2003). Furthermore, we make some simplifying assumptions on some relevant issues. For instance, we do not consider a separate market for green electricity (renewable energy). Also, in the case of combined heat and power (CHP) generation, we do not take into account the heat market. Finally, we do not consider substitution opportunities between natural gas and electricity, but we do consider substitution possibilities among generation technologies.
} 


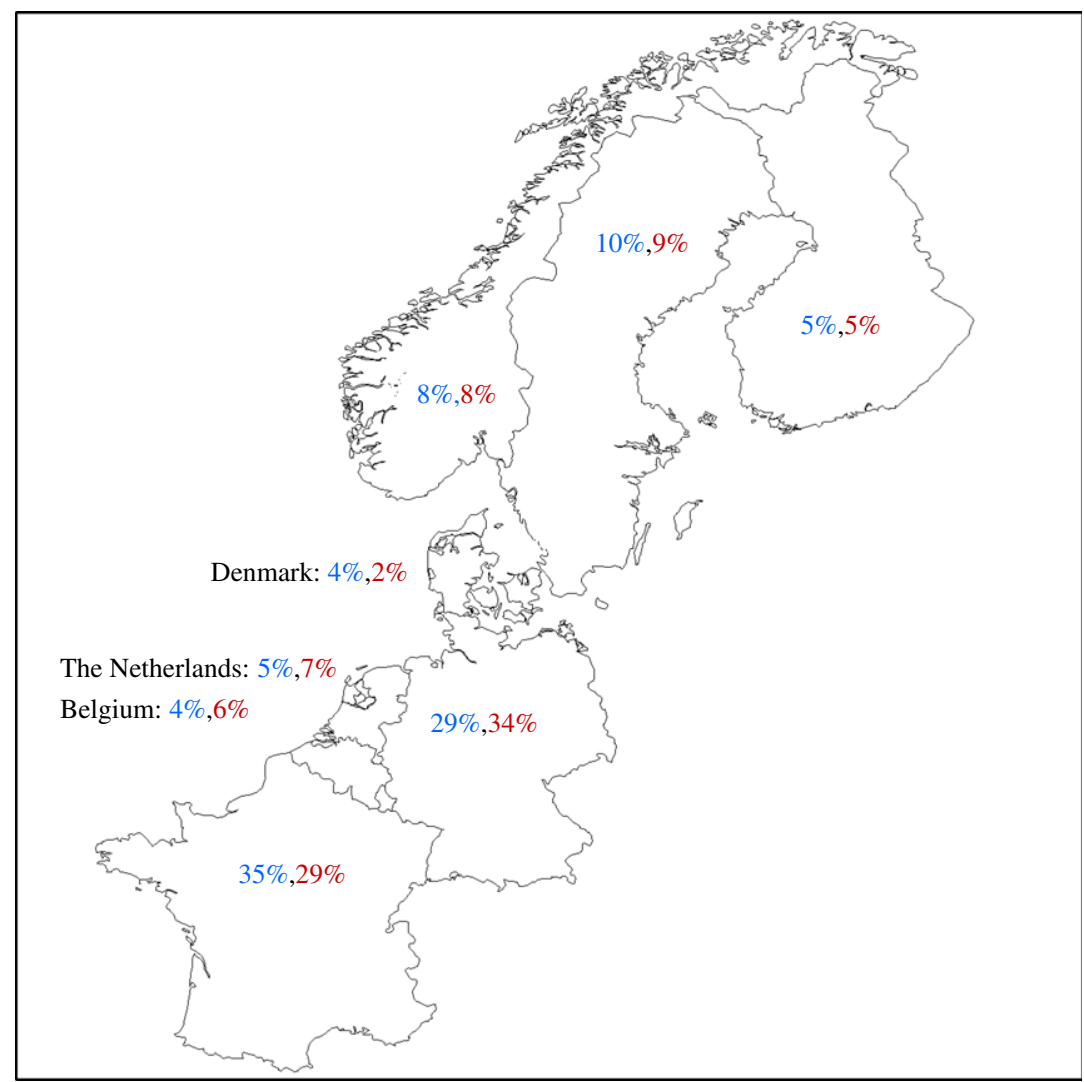

Fig. 1. The electricity market in eight European countries. Note: The first percentages represent shares in electricity capacity and the second percentages represent shares in demand for electricity.

showing that due to geographical variation, differences in production technologies and market structures, some country or countries do not follow the general trend. The elasticity turns out to be the most sensitive parameter of the model. For instance, a low elasticity pushes down the maximum allowable market share to the elasticity value, leading to a steep rise in market prices under strategic competition.

From a dynamic perspective, the existing capacities of firms and transmission may change due to investments and depreciation. For instance, a firm's investment in capacity increases the firm's market share and the ability to exercise market power, increasing market prices. Investments in transmission capacity lower congestion and also the ability of firms to exercise market power, lowering market prices. Investment decisions are not considered in this paper; we focus on the economic and environmental impacts of liberalisation within the present capacity structure.

Bower et al. (2001) have simulated the liberalised German electricity market using an agent-based model. They conclude that mergers increase market power leading to higher electricity prices. Their model is very sensitive to the out-phasing of expensive oil-fired plants, nuclear energy, and to closing the borders to imports of (cheap) electricity. In all these instances, prices jump up considerably. Bigano and Proost (2002) conducted a four-country study (France, Germany, Belgium, the Netherlands), which is linked through electricity trade. The environmental impacts are quantified and a 3-stage game is calculated in a partial equilibrium framework. They compare strategic action with perfect competition to conclude that phasing out nuclear energy leads to a substantial decrease in social welfare. Newberry (2001, 2002) discusses the potential difficulties in liberalising the EU electricity market. He argues that, due to insufficient regulation, the targeted lower price effect can be offset.

Several authors have examined different non-cooperative games within various markets. Murphy et al. (1982) have demonstrated how mathematical programming approaches can be used to determine oligopolistic market equilibria. Salant and Shaffer (1999) have illustrated the theoretical impacts on production and social welfare via two-stage Cournot-Nash equilibrium solutions, where learning-by-doing and investments in R\&D determine marginal costs of identical agents differently. For Europe, Jing-Yuan and Smeers (1999) have modelled an oligopolistic electricity market with a sophisticated game theoretic model. More generally, Helman et al. (1999) have investigated different kind of trade options and strategic price setting within the 
electricity market. Stern (1998) and Boots et al. (2004) have investigated the liberalisation of the European gas market.

The outline of this paper is as follows. The next section provides a general introduction to the model. The required data and the calibration of the model to the European liberalised electricity market are presented in Section 3. Section 4 presents some illustrative results to demonstrate the scope of the model. The final section concludes. The appendix provides a mathematical description of the model.

\section{The model}

This paper develops the computational game theoretic model EMELIE. This model can be considered as a numerical model, which can derive the outcome of competition among firms in an oligopolistic market. Energy producers generate electricity through different technologies. A producer can own several power plants, of which total capacity for each technology is considered, as well as variable production costs.

In the EMELIE model electricity producers maximise profit. The electricity demand curve is exogenous. Prices clear national markets. Trade is only feasible with neighbouring countries and includes netting, which means that bi-directional flows between two countries are permitted, as long as trade constraints are not violated. Emissions are assigned to producers based on the actual technology used. The EMELIE model also determines marginal production, capacity, trade and environmental costs, produced and traded electricity per technology and firm.

The model is calibrated by country-wise actual demand in a particular base year, which in this paper is taken to be year 2000. The model is calibrated on a perfect competitive market with fixed consumer demand where trade of electricity is permitted. This results in market clearing reference prices and the reference level of emissions. In the perfectly competitive market marginal costs are equal to marginal revenues, i.e. firms make zero profits and act as if they could not influence the market price. This case can be characterised as a perfectly competitive equilibrium and is referred to as the COMP case. The competitive equilibrium is equivalent to the Bertrand equilibrium in oligopoly competition, where firms set prices taking the pricesetting behaviour of other firms into account.

Yet competition can also be "strategic" in the sense that firms set produced quantities taking into account the quantities set by other firms, which will result in prices being higher than marginal costs. This difference is caused by the ability of electricity producers to exercise market power, which is also known as the market power mark-up. Each firm decides on the
Table 1

Overview of scenarios

\begin{tabular}{lll}
\hline & \multicolumn{2}{l}{ Environment: } \\
\cline { 2 - 3 } Market structure: & Unrestricted & $\begin{array}{l}30 \% \text { greenhouse } \\
\text { gas emission } \\
\text { reduction }\end{array}$ \\
\hline $\begin{array}{lll}\text { Perfect competition } \\
\text { Strategic competition }\end{array}$ & COMP & $\begin{array}{l}\text { RCOMP } \\
\text { Strategic competition }+ \text { demerger }\end{array}$ \\
\hline
\end{tabular}

quantity to produce, taking into account that the other players follow the same strategy. This situation is solved by calculating the Cournot-Nash equilibrium in the oligopoly model, which is characterised by simultaneous mutual strategic (re)actions by other firms. In the solution of this game the strategies of all market actors are best responses to the actions of all other market players. Furthermore, a so-called competitive fringe, consisting of the total sum of small and decentralised production units, has also been included. This fringe is assumed to behave as price takers, as in the COMP case. We refer to the case where large firms strategically exercise market power by setting quantities and the competitive fringes are price takers as the STRA case.

The Annex provides a more detailed description of the EMELIE model, including the mathematical formulas.

In order to study possible environmental consequences of liberalisation, we add environmental constraints to the model. Since the electricity sector has a considerable potential for greenhouse gas emission reduction, we consider the case of achieving a 30\% lower level of emissions with respect to the levels of greenhouse gas emissions in 2000 (in the COMP case). To study the influence of market power we consider consecutively three cases, namely perfect competition (RCOMP) and strategic competition (RSTRA). In addition, we consider a third scenario (RSTRADM) where the near-monopolies in France and Belgium are demerged into four parts, namely a respective proportional redistribution of production capacity of $30 \%$, $25 \%, 25 \%$ and $20 \%$ over all production technologies (following the demerger scenarios in Becker et al., 2004). A demerger into four firms with the same proportional production technology mix is sufficient to obtain a moderately concentrated market (Table 1).

\section{Calibration to the Northwestern European electricity market}

We calibrate the EMELIE model by considering production capacities of the largest producers, variable production costs for different technologies, transmission 
Table 2

Characteristics of eight European electricity markets in 2000

\begin{tabular}{lllllcccc}
\hline & BEL & DEN & FIN & FRA & GER & NLD & NOR & SWE \\
\hline Number of firms & 2 & 3 & 3 & 2 & 5 & 5 & 7 \\
Net losses & $4.5 \%$ & $6.5 \%$ & $3.5 \%$ & $6.8 \%$ & $4.7 \%$ & $3.9 \%$ & $8.9 \%$ & $8.2 \%$ \\
Average demand (GW) & 9.04 & 3.75 & 8.72 & 46.88 & 54.45 & 11.48 & 12.66 & 15.46 \\
\hline
\end{tabular}

Source: IEA (2002) and IEA (2003). Demand during base and peak loads are derived as explained in the text.

capacities between countries, together with wholesale market price and demand data.

\subsection{The demand side}

The demand side of the model consists of one sector per national market. However, there are different markets for peak load (high demand) and base load (moderate demand). It is useful to make this distinction. On the one hand, most electricity is generally consumed during periods of moderate demand, for which sufficient and relatively cheap generation technologies are generally used. On the other hand, demand for electricity can jump up during certain periods in the year. Then on top of the technologies as used during base load, relatively more expensive technologies follow in the dispatch merit order. We assume that $20 \%$ of the year is peak load and the remaining $80 \%$ is base load.

The values for the reference demand $d^{0}$ are presented in Table $2 .{ }^{4}$ In order to derive the reference demand under peak and base load, we additionally assume that demand at peak hours requires $90 \%$ of total available capacity: $d_{\text {peak }}^{0}=0.9 \sum_{f \varepsilon F} \sum_{i \varepsilon I} q_{i, f}^{\max }$. The resulting demands are comparable to the realised values during peak and base load hours in 2000 .

Table 2 shows that the number of firms is not evenly distributed across countries. In addition, as explained before, there is a fictive firm in all countries, namely a price-taking competitive fringe. These national fringes are actually a collection of individual and decentralised electricity production units, which often have a limited amount of total production capacity. In the case of the Netherlands, however, the fringe owns approximately $30 \%$ of total electricity capacity. In Belgium and France, where the liberalisation process is being introduced the latest, there is only one electricity producer next to the fringe, which can serve the whole local market and beyond.

The price elasticity of demand is assumed to be a flat -0.4 , which is the same for base and peak load. This

\footnotetext{
${ }^{4}$ To make the upcoming tables more readable, we use the following acronyms to refer to the 8 countries in the remainder of this paper: Belgium (BEL), Denmark (DEN), Finland (FIN), France (FRA), Germany (GER), the Netherlands (NLD), Norway (NOR), and Sweden (SWE).
}

value is based on average values found in the literature (see for example Andersson (1997); Brubakk et al. (1995); Grohnheit (2003) and Koopmans et al. (1999)). One might argue that this value of price elasticity is rather high, but as argued in the survey of Pineau and Murto (2003), a price elasticity of -0.4 reflects the alternatives for consumers to choose their electricity supplier.

Firms in the EMELIE model are assigned to one specific country. The model includes the opportunity to trade electricity between countries. However there are two restrictions. Firstly, imports from and exports to countries outside the EU8 are ignored in the model. This is a fairly good assumption for Germany, where imports nearly equal exports, while the production capacity of net exporter EdF is somewhat overestimated. Secondly, trade in the model is only allowed between neighbouring countries. The interregional transport capacity of the electricity network $\left(\eta_{r^{*} r}\right)$ is as presented in Table 3 .

Note that Table 3 is asymmetric in order to better reflect actual transmission capacities between countries. For instance, the interconnection capacity from France to Belgium (2850 MW) is larger than the capacity from Belgium to France $(2500 \mathrm{MW})$. The transmission capacity within a country is assumed to be sufficient to avoid local congestion.

\subsection{The supply side}

The supply side of the model consists of a number of electricity producers that produce and sell electricity. For each producer the production capacities of different production technologies are specified. To account for the great number of decentralised production units, a competitive fringe is added to the model. As these are aggregations of very small independent production units, it is reasonable to assume that they act as price takers in the model.

The model allows for many different production technologies. The current model considers 12 different production technologies, namely conventional thermal power technologies are nuclear $(\mathrm{N})$, coal $(\mathrm{C})$, gas $(\mathrm{G})$, lignite $(\mathrm{L})$ and oil $(\mathrm{O})$. There are five different types of combined heat and power production (CHP): gas (CHP$\mathrm{G})$, coal (CHP-C), oil (CHP-O), biomass (CHP-B) and other fuels (CHP-X). Finally, besides CHP-B, hydro (H) 
Table 3

Transmission capacities between EU8 countries in MWs

\begin{tabular}{|c|c|c|c|c|c|c|c|c|}
\hline & BEL & DEN & FIN & FRA & GER & NLD & NOR & SWE \\
\hline Belgium & & & & 2500 & & 1400 & & \\
\hline Denmark & & & & & 1750 & & 950 & 1900 \\
\hline Finland & & & & & & & 70 & 1450 \\
\hline France & 2850 & & & & 1150 & & & \\
\hline Germany & & 1350 & & 1750 & & 3300 & & 550 \\
\hline The Netherlands & 1400 & & & & 3300 & & & \\
\hline Norway & & 950 & 70 & & & & & 3035 \\
\hline Sweden & & 1840 & 2050 & & 550 & & 3035 & \\
\hline
\end{tabular}

Note: Empty cells mean that the countries are not neighbouring countries.

Source: www.etso-net.org and own calculation.

Table 4

Electricity production capacities in 2000

\begin{tabular}{|c|c|c|c|c|c|c|c|c|}
\hline$(\mathrm{GW})$ & BEL & DEN & FIN & FRA & GER & NLD & NOR & SWE \\
\hline Nuclear & 5.71 & & 2.64 & 63.18 & 21.37 & 0.45 & & 9.46 \\
\hline Coal & 2.95 & 5.10 & 2.29 & 12.69 & 17.86 & 4.05 & & \\
\hline Lignite & & & & & 18.97 & & & \\
\hline Gas & 3.50 & 0.04 & 0.90 & 1.89 & 13.82 & 7.17 & & \\
\hline Oil & 1.20 & 0.79 & 1.24 & 12.23 & 8.11 & 0.99 & & 4.64 \\
\hline CHP-gas & 0.58 & 2.58 & 1.80 & & 0.99 & 4.66 & & 0.13 \\
\hline CHP-coal & & 1.13 & 1.47 & & 6.96 & & & 0.56 \\
\hline CHP-oil & 0.10 & & 0.16 & & 0.30 & & & 0.65 \\
\hline CHP-bio & 0.29 & 0.23 & 1.04 & & & 0.64 & & 0.46 \\
\hline CHP-others & & & 1.44 & 6.64 & & & 0.20 & 1.00 \\
\hline Hydro & 1.40 & 0.01 & 2.88 & 25.60 & 11.61 & 0.04 & 27.46 & 16.33 \\
\hline Wind & 0.01 & 2.42 & 0.04 & 0.08 & 0.36 & 0.44 & 0.01 & 0.25 \\
\hline Total & 15.74 & 12.30 & 15.89 & 122.31 & 100.33 & 18.44 & 27.67 & 33.48 \\
\hline
\end{tabular}

Notes: The capacity is corrected for availability, where the capacity taken out for reserve and regulation is not included, such that the capacities presented here can potentially be used for $24 \times 365 \mathrm{~h}$. Empty cells mean that the technology is not present in the country.

Table 5

Variable costs $(€ / \mathrm{MWh})$ per technology in 2000

\begin{tabular}{|c|c|c|c|c|c|c|c|c|}
\hline & BEL & DEN & FIN & FRA & GER & NLD & NOR & SWE \\
\hline Nuclear & 6.14 & & 6.14 & 6.14 & 6.14 & 6.14 & & 7.50 \\
\hline Coal & 16.94 & 13.83 & 13.97 & 15.19 & 14.42 & 16.83 & & \\
\hline Lignite & & & & & 15.50 & & & \\
\hline Gas & 24.22 & 23.81 & 20.28 & 23.83 & 29.04 & 23.25 & & \\
\hline Oil & 36.42 & 35.21 & 35.21 & 38.84 & 38.70 & 41.21 & & 39.83 \\
\hline CHP-gas & 13.29 & 13.08 & 11.21 & & 15.85 & 12.78 & & 13.52 \\
\hline CHP-coal & & 7.57 & 7.63 & & 7.84 & & & 11.73 \\
\hline CHP-oil & 19.58 & 19.58 & 19.58 & & 21.43 & & & 21.58 \\
\hline CHP-bio & 19.94 & 19.94 & 19.94 & & & 19.94 & & 19.94 \\
\hline CHP-others & & & 14.59 & 16.69 & & & 16.69 & 16.69 \\
\hline Hydro & 0.00 & 0.00 & 0.00 & 5.84 & 0.00 & 0.00 & 0.00 & 1.18 \\
\hline Wind & 0.00 & 0.00 & 0.00 & 0.00 & 0.00 & 0.00 & 0.00 & 0.00 \\
\hline
\end{tabular}

Source: Own calculations based on AKF (1997), ECB (2001), EUL (2002), IEA (2003), SE (2000), and STEM (2000).

and wind power (W) are also available renewable technologies in the model.

A brief summary of the total production capacities in these countries is given in Table 4 .
Available technologies differ between countries and not all technologies are present in each country. For each country and technology variable production costs have been specified, which are shown in Table 5. 
Also variable production costs differ between countries, which are the result of varying fuel and production taxes across countries. Although it should be noted that relative costs between different technologies are roughly the same in all countries.

\subsection{Emission coefficients}

With respect to the environment, the model takes three environmental effects into account, namely greenhouse gas emissions, acidification, and smog formation due to emissions of fine particles. For all technologies, we have determined the specific emissions of Belgium, Denmark, Germany, Finland, France, the Netherlands, Norway and Sweden due to electricity generation.

To this end the ExternE emission database (ExternE, 1999) has been updated to the year 2000 and completed by source and country. Emissions due to mining, extraction, transportation, construction and deconstruction of power plants have been disregarded, as these emissions, including emissions of extraction and transportation, are in the same range of those for wind or hydroelectric power (ExternE, 1999, German implementation). Consequently emissions of hydroelectric, nuclear and wind power are set to zero. $\mathrm{CO}_{2}$ emissions of biomass power are also set to zero.
For the 12 technologies, we have used emission factors for six gases, namely $\mathrm{CO}_{2}, \mathrm{SO}_{2}, \mathrm{NO}_{x}, \mathrm{CH}_{4}$, $\mathrm{N}_{2} \mathrm{O}$ and PM10. From these gases, we have derived greenhouse gas emissions, acidification, and smog formation (due to emissions of fine particles). For greenhouse gases we use $\mathrm{CO}_{2}$ emission equivalents, where $0.310 \mathrm{~kg} \mathrm{~N}_{2} \mathrm{O}=0.021 \mathrm{~kg} \mathrm{CH}_{4}=1 \mathrm{~kg} \mathrm{CO}$. One unit of acidification is equivalent to $1 / 32 \mathrm{SO}_{2}=1 / 46$ $\mathrm{NO}_{2}$. The emission factor of smog is simply the amount of PM10 emitted. The emission factors differ across technologies and countries. Tables 6-8 present the emission factors. The empty cells mean that the technology is not used in the country. Nuclear, hydro and wind are not presented in the tables are their emission coefficients are zero in all instances.

Environmental impacts result from different emission factors. The emission factors vary among technologies of electricity production per country.

\section{Results}

Table 9 shows the resulting prices and supply in the EU8 for the six different scenarios introduced in Section 2. The total electricity supply in the EU8 is $1423 \mathrm{TWh}$ at an average price of $20.79 € / \mathrm{MWh}$ (COMP scenario).

Table 6

Greenhouse gas emission factors ( $\mathrm{kg} \mathrm{CO}_{2}$ equivalents/MWh) per technology in the EU8 countries

\begin{tabular}{|c|c|c|c|c|c|c|c|c|}
\hline & BEL & DEN & FIN & FRA & GER & NLD & NOR & SWE \\
\hline Coal & 920.0 & 972.2 & 915.9 & 915.9 & 970.0 & 915.9 & & \\
\hline Lignite & & & & & 1219.7 & & & \\
\hline Gas & 388.0 & 327.2 & 348.9 & 401.9 & 348.9 & 411.0 & & \\
\hline Oil & 877.3 & 692.6 & 877.3 & 756.8 & 877.3 & 877.3 & & 877.3 \\
\hline CHP-gas & 330.6 & 673.9 & 528.3 & & 327.1 & 327.1 & & 327.1 \\
\hline CHP-coal & & 948.9 & 776.1 & & 33.1 & & & 733.1 \\
\hline CHP-oil & 503.4 & & 503.4 & & 503.4 & & & 503.4 \\
\hline CHP-bio & 0.0 & 81.9 & 2.1 & & & 0.0 & & 0.0 \\
\hline CHP-others & & & 1296.1 & 401.6 & & & 403.4 & 403.4 \\
\hline
\end{tabular}

Source: ExternE (1999) and own calculations.

Table 7

Emission factors for acidifying emissions (g acid equivalents/MWh) per technology in the EU8 countries

\begin{tabular}{|c|c|c|c|c|c|c|c|c|}
\hline & BEL & DEN & FIN & FRA & GER & NLD & NOR & SWE \\
\hline Coal & 31.549 & 20.699 & 23.310 & 31.549 & 23.307 & 28.365 & & \\
\hline Lignite & & & & & 33.896 & & & \\
\hline Gas & 5.901 & 2.174 & 4.522 & 15.435 & 4.522 & 6.783 & & \\
\hline Oil & 21.821 & 2.486 & 21.821 & 25.610 & 21.821 & 21.821 & & 21.821 \\
\hline CHP-gas & 2.174 & 19.833 & 6.848 & & 2.174 & 2.174 & & 2.174 \\
\hline CHP-coal & & 20.217 & 32.459 & & 2.649 & & & 2.649 \\
\hline CHP-oil & 2.486 & & 2.486 & & 2.486 & & & 2.486 \\
\hline CHP-bio & 7.160 & 31.692 & 46.726 & & & 7.160 & & 12.288 \\
\hline CHP-others & & & 83.071 & 15.435 & & & 3.736 & 3.736 \\
\hline
\end{tabular}

Source: ExternE (1999) and own calculations. 
Table 8

Emission factors for smog formation ( $\mathrm{g}$ fine particles/MWh) per technology in the EU8 countries

\begin{tabular}{|c|c|c|c|c|c|c|c|c|}
\hline & BEL & DEN & FIN & FRA & GER & NLD & NOR & SWE \\
\hline Coal & 80.0 & 57.0 & 172.9 & 170.0 & 66.0 & 17.0 & & \\
\hline Lignite & & & & & 96.0 & & & \\
\hline Gas & 0.0 & 0.0 & 0.0 & 0.0 & 0.0 & 0.0 & & \\
\hline Oil & 21.0 & 1.0 & 3.0 & 130.0 & 2.0 & 2.0 & & 21.0 \\
\hline CHP-gas & 0.0 & 0.0 & 0.0 & & 0.0 & 0.0 & & 0.0 \\
\hline CHP-coal & & 57.0 & 150.0 & & 10.0 & & & 10.0 \\
\hline CHP-oil & 1.0 & & 2.0 & & 2.0 & & & 2.0 \\
\hline CHP-bio & 30.0 & 0.0 & 21.0 & & & 30.0 & & 233.0 \\
\hline CHP-others & & & 195.0 & 0.0 & & & 1.0 & 1.0 \\
\hline
\end{tabular}

Source: ExternE (1999) and own calculations.

Table 9

Results in terms of prices in eight countries, overall supply and dead weight loss for six scenarios

\begin{tabular}{|c|c|c|c|c|c|c|}
\hline & COMP & STRA & STRADM & RCOMP & RSTRA & RSTRADM \\
\hline Belgium & 22.94 & 37.56 & 31.13 & 30.30 & 42.95 & 32.13 \\
\hline Denmark & 25.06 & 27.96 & 27.62 & 28.52 & 32.71 & 29.37 \\
\hline Finland & 20.41 & 23.16 & 22.99 & 24.08 & 25.77 & 23.97 \\
\hline France & 18.84 & 37.30 & 28.83 & 20.75 & 42.37 & 29.26 \\
\hline Germany & 21.83 & 31.04 & 32.07 & 30.38 & 38.10 & 33.69 \\
\hline The Netherlands & 23.38 & 30.19 & 29.86 & 30.50 & 36.56 & 31.45 \\
\hline Norway & 18.03 & 21.42 & 21.26 & 20.65 & 23.43 & 21.98 \\
\hline Sweden & 21.28 & 24.32 & 24.10 & 24.33 & 26.93 & 24.94 \\
\hline EU8 & 20.79 & 30.75 & 28.58 & 25.67 & 35.85 & 29.65 \\
\hline Supply (TWh) & 1423 & 1192 & 1222 & 1308 & 1115 & 1203 \\
\hline Deadweight loss (M€) & 0 & 1629 & 1343 & 0 & 1729 & 570 \\
\hline
\end{tabular}

The average electricity prices do not differ much and vary from $18 € / \mathrm{MWh}$ in Norway to $25 € / \mathrm{MWh}$ in Denmark.

A number of insights can be derived from Table 9. In the COMP case, all electricity producers act as price taker, which means that they produce electricity regardless of the electricity supply of their competitors equalling marginal cost to the market price.

In the strategic competition scenarios the electricity prices are considerably higher than in the perfect competition scenarios. Without exception the electricity prices increase in all strategic competition scenarios, where large firms exercise market power. This also leads to a non-negative weighted average dead weight loss (the area above the supply curve, below the demand curve and right of the equilibrium price), which is a measure for market imperfection.

A demerger in France and Belgium leads to a lower price increase, which results in a lower dead weight loss. However, in comparing STRA with STRADM we see that the prices increase in Germany, while the price are lower in all other countries and considerably lower in France and Belgium. The price increase in Germany is probably caused by the shift in market concentration from France and Belgium to Germany.

In comparing the prices in scenarios without environmental constraints (COMP, STRA) with scenarios with environmental constraints (RCOMP, RSTRA) we can see that the average annual prices increase with about 5 $€ / \mathrm{MWh}$, while the permit price is nearly $9 € / \mathrm{MWh}$ (see Table 13).

\subsection{Decomposition of marginal costs}

In addition to the effects of market power and environmental constraints on wholesale electricity prices, we can also take a further look into the first order optimality conditions of the EMELIE model (e.g. Eq. (11) in the appendix). This implies that the wholesale electricity price is not only driven by production costs, but also, on the one hand, the restrictedness of the different restrictions, measured via shadow prices, and, on the other hand, the amount market power exercised by large firms.

In order to decompose the total marginal costs, we need to consider the weighted averages of the marginal production costs, and the shadow prices of production 
capacity, trade and environment. An appropriate weight factor is the amount of production minus transmission losses. Table 10 presents the results of the decomposition of the prices of RCOMP and RSTRA to illustrate the joint effect of market power and an environmental constraint. Under perfect competition all components add up to the market-clearing prices. Under strategic competition there remains a difference, namely the market power mark-up as shown in Table 11.

Table 10 indicates that the weighted average marginal costs under perfect competition (RCOMP) on average contribute a share of $43 \%$ to cover production costs, $47 \%$ to keep the capacity up and running, $2 \%$ for trade and $8 \%$ to meet environmental constraints. This decomposition also provides us with a number of additional insights.

The weighted average marginal production costs decrease in Denmark and Sweden, if we compare scenarios of strategic competition (RSTRA) with scenarios of perfect competition (RCOMP), while the weighted average marginal production costs increase in all other countries. Overall the weighted average marginal production costs increase. From this we can draw an interesting conclusion, namely that in the case of strategic competition, electricity is not necessarily produced at the places where it is cheapest to do so, as firms with market power can distort the market.

The weighted average marginal production capacity costs are on the average lower under strategic competition than under perfect competition. There is, however, one exception, namely Denmark. A lower weighted average marginal capacity cost simply follows the idea that production is lower. However, due to market power distortions, exceptions are possible. Overall, the weighted average marginal capacity cost is always high in Sweden, while it is always low in Finland. This means that production capacity is scarce in Sweden and there is overcapacity in Finland.

Consideration of the weighted average marginal trade price also leads to a number of additional insights.
There is a large incentive to export to markets with relatively high prices like Belgium under perfect competition and France and Germany under strategic competition. Here we find the highest weighted average marginal trade costs. The addition of environmental constraints to the model increases the attractiveness of the Dutch firms to export electricity, due to relatively higher prices in neighbouring markets (see Table 9), which reduces the weighted average marginal trade costs. This increased export mainly goes to Germany. In Norway and Sweden the weighted average marginal trade cost is even zero. Hence, the import constraint is never binding and this implies that they have such a strong incentive to sell their locally produced electricity abroad that they become net exporters.

Finally, the weighted average marginal environmental costs can also be considered. The reduction target is most binding under perfect competition (equal to a permit price of $8.9 €$ per tonne $\mathrm{CO}_{2}$ equivalent) and somewhat less restrictive under strategic competition (equal to a permit price of $8.7 €$ per tonne $\mathrm{CO}_{2}$ equivalent). The weighted average marginal environmental cost is the highest in Germany, followed by

Table 11

Lerner index in eight countries for four scenarios of strategic competition

\begin{tabular}{lllll}
\hline & STRA $(\%)$ & $\begin{array}{l}\text { STRADM } \\
(\%)\end{array}$ & RSTRA (\%) & $\begin{array}{l}\text { RSTRADM } \\
(\%)\end{array}$ \\
\hline Belgium & 43.7 & 21.8 & 44.3 & 20.9 \\
Denmark & 12.6 & 12.6 & 16.7 & 14.6 \\
Finland & 11.5 & 11.6 & 12.7 & 12.5 \\
France & 36.2 & 31.5 & 36.9 & 31.8 \\
Germany & 34.3 & 24.3 & 30.3 & 23.4 \\
The & 21.3 & 17.6 & 18.8 & 16.7 \\
Netherlands & & & & \\
Norway & 10.3 & 10.3 & 11.0 & 10.6 \\
Sweden & 18.1 & 18.0 & 19.9 & 18.4 \\
EU8 & 30.1 & 23.2 & 29.1 & 23.0 \\
\hline
\end{tabular}

Table 10

Decomposition of marginal cost for ten scenarios

\begin{tabular}{|c|c|c|c|c|c|c|c|c|}
\hline & \multicolumn{2}{|c|}{ Production } & \multicolumn{2}{|l|}{ Capacity } & \multicolumn{2}{|l|}{ Trade } & \multicolumn{2}{|c|}{ Environment } \\
\hline & RCOMP & RSTRA & RCOMP & RSTRA & RCOMP & RSTRA & RCOMP & RSTRA \\
\hline Belgium & 10.73 & 16.45 & 14.04 & 5.26 & 4.63 & 0.00 & 0.90 & 2.23 \\
\hline Denmark & 12.28 & 10.95 & 12.63 & 14.45 & 0.27 & 0.15 & 3.34 & 1.70 \\
\hline Finland & 12.27 & 12.55 & 9.39 & 7.67 & 0.17 & 0.17 & 2.26 & 2.10 \\
\hline France & 10.21 & 16.78 & 10.01 & 5.27 & 0.00 & 1.60 & 0.53 & 3.10 \\
\hline Germany & 12.12 & 12.75 & 13.27 & 9.13 & 0.40 & 1.75 & 4.59 & 2.93 \\
\hline The Netherlands & 17.07 & 17.45 & 10.09 & 9.24 & 0.18 & 0.00 & 3.16 & 3.01 \\
\hline Norway & 8.69 & 11.95 & 11.95 & 8.70 & 0.00 & 0.00 & 0.01 & 0.20 \\
\hline Sweden & 7.57 & 6.90 & 16.51 & 13.68 & 0.00 & 0.00 & 0.25 & 0.98 \\
\hline EU8 & 11.09 & 13.53 & 12.08 & 8.48 & 0.40 & 1.00 & 2.10 & 2.40 \\
\hline
\end{tabular}


Denmark and the Netherlands. From this we can draw an important policy conclusion, namely that it is relatively costly for these countries to reduce greenhouse gas emissions in the EU8 electricity market. We can also observe that near-monopoly markets (France and Belgium) see an increase in the weighted average marginal environmental cost by moving from perfect to strategic competition, while there is a substantial reduction in the weighted average marginal environmental cost in Denmark and Germany.

While the four shares of weighted average marginal production, capacity, trade and environmental costs add up to the equilibrium wholesale electricity prices under perfect competition; it is not the case for the strategic competition scenarios. As can be seen from Table 10, for these scenarios a difference between the wholesale prices and the sum of weighted average marginal production, capacity, trade and environmental costs emerged due to the exercise of market power in the national electricity wholesale markets. This difference is also known as the Lerner index, which is equal to (price-marginal cost)/ price. Table 11 presents these Lerner indices.

As expected, the Lerner indices are the highest in the near-monopoly Belgian and French markets. The demerger scenarios reduce the Lerner index more in the Belgian than in the French market, while the ability to exercise market power becomes the highest in the French market. A possible reason for this somewhat anti-intuitive result is that the French market is the largest in the EU8, with a share of $35 \%$ of production capacity. The market power mark-up is always the lowest in Norway at around $10 \%$, which has many small firms competing on the market. The introduction of environmental constraints tends to increase market power, while there is a decrease in Germany. The latter is possibly caused by the relatively unfavourable position of Germany in curbing carbon emissions. The overall effect of the demergers is that market power is reduced in the EU8 market.

\subsection{Individual firms}

Table 12presents the payoff for firms that demerge (EdF and Electrabel) in million Euros (see Eq. (1)).

From Table 12 we can see that the imposition of environmental constraints leads to a welfare transfer from the consumer (higher prices) to the producer (higher payoffs). Demerging EdF and Electrabel can reduce this welfare transfer. This leads to a change in total payoffs by $-3 \%$ (without environmental constraint) and $-15 \% \quad(30 \%$ greenhouse gas emission reduction). The demerger changes the payoffs of Electrabel with $-10 \%$ without and $-21 \%$ with environmental constraint, while the payoff of EdF changes with $+2 \%$ without and $-3 \%$ with environmental constraint.

\subsection{Environment}

We derive environmental impacts by calculating emissions from different applied technologies. In the COMP scenario, the levels of emissions are $440 \mathrm{Mt} \mathrm{CO}_{2}$ equivalents, $10.7 \mathrm{kt}$ acid equivalents, and $28.4 \mathrm{kt}$ PM10 emissions. The effect of different scenarios on greenhouse gas, acidifying and fine particle emissions relative to the COMP scenario are presented in Table 13.

Table 13 show that the difference in emissions with respect to the reference scenario point in the same direction for each pollutant for all the six scenarios. However, the reduction in acid and fine particle emissions tend to be somewhat higher under a more

Table 12

Payoff per firm (Million euros) for six different scenarios

\begin{tabular}{lrrrrrr}
\hline & COMP & STRA & STRADM & RCOMP & RSTRA & RSTRADM \\
\hline Electrabel & 795 & 1285 & 1156 & 1165 & 1499 & 1189 \\
EdF & 4096 & 6237 & 6387 & 5110 & 6667 & 6495 \\
All firms & 16766 & 25483 & 24638 & 23001 & 29521 & 25112 \\
\hline
\end{tabular}

Table 13

Per cent change in emissions with respect to 2000 levels under different scenarios and the required greenhouse gas permit price

\begin{tabular}{lllllll}
\hline & COMP $(\%)$ & STRA $(\%)$ & STRADM $(\%)$ & RCOMP $(\%)$ & RSTRA $(\%)$ & RSTRADM $(\%)$ \\
\hline Greenhouse gases & 0 & -9.7 & -23.6 & -30.0 & -30.0 & -30.0 \\
Acidifying gases & 0 & -6.3 & -24.3 & -34.1 & -30.0 & -32.5 \\
Fine particles & 0 & -9.1 & -26.8 & -31.0 & -34.5 & -35.5 \\
Greenhouse gases & & 0 & 0 & 8.91 & 8.67 & 2.62 \\
Permit price $(€ / \mathrm{kt})$ & 0 & 0 & & & & \\
\hline
\end{tabular}


stringent carbon reduction policy. This means that a carbon restriction reduces the acidification and smog problem as well "for free".

The environmental impacts of different scenarios of producer behaviour are as follows. Without emission restrictions, under strategic competition, greenhouse gas emissions $(-9.7 \%)$ as well as acidification $(-6.3 \%)$ and smog formation $(-9.1 \%)$ decline compared to base year 2000 , due to lower levels of electricity demand. In the case with the French/Belgian demerger the required permit price is $2.6 € / \mathrm{t}$ carbon, which is much lower than the $8.7 € / \mathrm{t}$ carbon that is required without the demerger. This demonstrates that a reduction in market power can be both beneficial for the consumer and the environment.

\section{Conclusions and outlook}

We presented the static computational game theoretic model EMELIE to investigate the impacts of competition on the wholesale price of electricity, the demand for electricity, the profits of firms, and different kinds of polluting emissions. Climate policy implies that emissions reduction targets need to be implemented, and we therefore assessed the consequences of a stricter climate policy in the electricity sector.

It turned out under perfect competition that $43 \%$ of the marginal costs of electricity are needed to cover production, $47 \%$ is needed to keep the production capacity up and running, $2 \%$ of the price is needed for trade and $8 \%$ is needed to meet environmental constraints. In the case of strategic competition the price of electricity increased with the market power mark-up, which is a cap or profit margin on top of the total marginal production costs.

From the marginal cost decomposition analysis we could draw two conclusions. First, in the case of strategic competition, electricity is not necessarily produced at the places where it is cheapest to do so, as firms with market power can distort the market. Second, from a marginal cost perspective it is relatively costly for Germany, to reduce greenhouse gas emissions in the Northwestern European electricity market.

The consequences of liberalisation for the environment are ambiguous. The exercise of market power can be both beneficial and harmful for the environment. In the case of strategic competition, all considered polluting emissions showed a decline in comparison to the perfect competition reference scenario. However, we also concluded that greenhouse gas emissions permit price is reduced in the case of a demerger in the Belgian and French market. This demonstrated that a reduction in market power could be both beneficial for the consumer and the environment.
In practice, there could be interdependence between different time periods. For instance, during periods of low demand it would be more attractive to use electricity for pumped storage, which could be used for generation during periods of peak load. This affects the actual production capacity available during different load periods and may affect firm's ability to exercise market power. Also start and stop costs of e.g. nuclear power may affect the possibilities of using market power in the short run. Inter-temporal modelling would be a fruitful direction for future research.

Two more extensions of the model are envisaged. Firstly, the EMELIE model will be developed into a dynamic model, so that long-term consequences of investment decisions on the liberalised electricity market can be assessed. It is particularly interesting to study the investment choices and price development over time with and without regulation for a number of future demand profiles. Secondly, it would be interesting to study cross-border ownership relations, where firms can own production capacity in different countries, and they can allocate their production across these countries. This implies that control over interconnection capacity can generate a new source of market power. These are all promising fields for future research towards which we intend to use the EMELIE model.

\section{Acknowledgement}

Funding from the EU (contract number NNE5-200100519) for the Electricity MarkEt Liberalization In Europe (EMELIE) project as well as funding from the Ministry of Science and Culture in Germany to build the model is gratefully appreciated. We are also grateful for the cautious reading, comments and suggestions provided by an anonymous referee. Any remaining errors are ours.

\section{Appendix. Mathematical description of the EMELIE model}

Table 14 presents the sets and indices, parameters and variables of the EMELIE model. ${ }^{5}$

In EMELIE firms maximise their payoff by choosing the amount of electricity to produce with various technologies at periods with various load types:

$\Pi_{f}=\sum_{l \in L} h_{l} \sum_{r \in R}\left[\left(p_{r, l}\left(S_{r, l}\right) s_{f, r, l}\right)-\left(\sum_{i \in I} c_{i, r^{*}}^{\mathrm{v}} q_{i, f, r, l}\right)\right]$.

\footnotetext{
${ }^{5}$ See also Lise and Linderhof (2004) for a more elaborate presentation of the model.
} 
Table 14

Indices, parameters and variables in the EMELIE model

\begin{tabular}{|c|c|c|}
\hline $\begin{array}{l}\text { Sets and } \\
\text { indices }\end{array}$ & Description & Units \\
\hline$F$ & Firms $f, g \in F$ & \\
\hline$I$ & Technologies $i \in I$ & \\
\hline$R$ & Regions/countries $r \in R$ & \\
\hline$L$ & Load period $l \in L=\{$ base, peak $\}$ & \\
\hline$K$ & $\begin{array}{l}\text { Emission type } k \in K=\{\text { greenhouse } \\
\text { gases, acid, smog }\}\end{array}$ & \\
\hline$F_{r^{*}}$ & Firms in country $r^{*}$ & \\
\hline \multicolumn{3}{|c|}{ Parameters: } \\
\hline$c_{i, r^{*}}^{\mathrm{v}}$ & Variable production costs & $€$ per $\mathrm{MWh}$ \\
\hline$d_{r, l}^{0}$ & Reference demand for electricity & TWh \\
\hline$p_{r, l}^{0}$ & Reference price for electricity & $€$ per $\mathrm{MWh}$ \\
\hline$\varepsilon_{r, l}$ & Price elasticity of electricity demand & \\
\hline$\lambda_{r, r^{*}}$ & Loss of electricity due to transport & $\%$ \\
\hline$\eta_{r, r^{*}}$ & Maximum trade possibility & MW \\
\hline$\sigma_{i, r^{*}, k}$ & Emission factor & g per $\mathrm{MWh}$ \\
\hline$q^{\max }{ }_{i, f}$ & Maximum production capacity & $\mathrm{GW}$ \\
\hline & Emission permits & $\mathrm{g}$ \\
\hline$h_{l}$ & Number of operating hours & \\
\hline$\xi_{f, l}$ & Reduction in 'market power' mark-up & \\
\hline \multicolumn{3}{|c|}{ Variables: } \\
\hline$\Pi_{f}$ & Payoff of firm $f$ & $€$ \\
\hline$L_{f}$ & Profit of firm $f$ & $€$ \\
\hline & Market price for electricity & $€$ per $\mathrm{MWh}$ \\
\hline$c^{\mathrm{m}}{ }_{i, f, r, l}$ & $\begin{array}{l}\text { Marginal costs of electricity } \\
\text { production }\end{array}$ & TWh \\
\hline$\mu_{i, f, l}$ & $\begin{array}{l}\text { ComplemShadow price of capacity } \\
\text { constraint }\end{array}$ & $€$ per $\mathrm{MWh}$ \\
\hline$\tau_{r, r^{*}, l}$ & Shadow price of trade constraint & $€$ per $\mathrm{MWh}$ \\
\hline$\kappa_{k}$ & Shadow price of emission constraint & $€$ per $\mathrm{MWh}$ \\
\hline$\vartheta_{f r, l}$ & Supply share of the market per firm & $\%$ \\
\hline$s_{f r, l}$ & Supply of electricity per firm & TWh \\
\hline$S_{r, l}$ & Total supply of electricity per region & TWh \\
\hline$q_{i, f, r, l}$ & Production of electricity & TWh \\
\hline$x_{r, r^{*}, l}$ & $\begin{array}{l}\text { Net trade between region } r \text { and region } \\
r^{*}\end{array}$ & TWh \\
\hline$E m_{k}$ & Current level of emissions & $\mathrm{g}$ \\
\hline
\end{tabular}

The EMELIE model accounts for a net-loss of $100 \lambda_{r^{*} r} \%$ :

$s_{f, r, l}=\left(1-\lambda_{r^{*}, r}\right) \sum_{i \in I} q_{i, f, r, l}$.

Consumers are price sensitive with a constant elasticity of $-\varepsilon_{r, l}$ :

$$
\begin{aligned}
d_{r, l}^{0}\left(\frac{p_{r, l}\left(S_{r, l}\right)}{p_{r, l}^{0}}\right)^{-\varepsilon_{r, l}} & =\sum_{f \in F}\left(1-\lambda_{r^{*}, r}\right) \sum_{i \in I} q_{i, f, r, l} \\
& =\left(\sum_{f \in F} s_{f, r, l}=S_{r, l}\right) .
\end{aligned}
$$

Firm's regional market shares $\left(\vartheta_{f, r, l}\right)$ are defined as

$$
\vartheta_{f, r, l} \sum_{\substack{g \in F \\ \operatorname{loc}(g)=r^{* *}}}\left(1-\lambda_{r^{* *}, r}\right) \sum_{i \in I} q_{i, g, r, l}=\left(1-\lambda_{r^{*}, r}\right) \sum_{i \in I} q_{i, f, r, l},
$$

where firm $f$ is located in region $r^{*}$ and firm $g$ is located in region $r^{* *}$.

The amount of trade is defined as the amount of net export from country $r^{*}$ to country $r$, which is the exported amount of electricity from region $r^{*}$ to region $r$ (the transport losses only concern the region of production) minus the imported amount of electricity entering region $r^{*}$ from region $r$ (the transport losses only concern the region of production), while firm $f$ is located in country $r^{*}\left(f \in F_{r^{*}}\right)$ :

$$
\begin{aligned}
x_{r^{*}, r, l}= & \sum_{f \in F_{r^{*}}}\left(1-\lambda_{r^{*}, r^{*}}\right) \sum_{i \in I} q_{i, f, r, l} \\
& -\sum_{g \in F_{r}}\left(1-\lambda_{r, r}\right) \sum_{i \in I} q_{i, g, r^{*}, l} .
\end{aligned}
$$

In the EMELIE model there is an upper bound to the production capacity:

$\sum_{r \in R} q_{i, f, r, l}-q_{i, f}^{\max } \leqslant 0 \perp 0 \leqslant \mu_{i, f, l}$,

where $\perp$ is used to denote complementarity with shadow price $\mu_{i, f, l}$.

The amount of electricity trade is also restricted:

$x_{r^{*}, r, l}-\eta_{r^{*}, r} \leqslant 0 \perp 0 \leqslant \tau_{r^{*}, r, l}$.

Furthermore, emissions can be constrained as well:

$\sum_{l \in L} h_{l} \sum_{r \in R} \sum_{i \in I} \sum_{f \in F} \sigma_{i, r^{*}, k} q_{i, f, r, l}-E_{k} \leqslant 0 \perp 0 \leqslant \kappa_{k}$,

where emission factors $\left(\sigma_{i, r^{*}, k}\right)$ are associated with the region of electricity production of firm $f$. Alternatively, emission trading can be modelled by increasing the production costs $\left(C_{i, r^{*}}^{\mathrm{v}}\right)$ by the permit price. Then restriction (8) can be omitted.

The complete optimisation problem of the electricity producer can be summarised into the following Lagrangian, where $L_{f}$ denotes the net profit:

$$
\begin{aligned}
L_{f}= & \sum_{l \in L} h_{l} \sum_{r \in R} \sum_{i \in I} p_{r, l}\left(S_{r, l}\right)\left(1-\lambda_{r^{*}, r}\right) q_{i, f, r, l}-c_{i, r^{*}}^{\mathrm{v}} q_{i, f, r, l} \\
& -\sum_{l \in L} h_{l} \sum_{i \in I} \mu_{i, f, l}\left(\sum_{r \in R} q_{i, f, r, l}-q_{i, f}^{\max }\right) \\
& -\sum_{l \in L} h_{l} \sum_{\substack{r \in R, r \neq r^{*}}} \tau_{r^{*}, r, l}\left(\sum_{f \in F_{r^{*}}}\left(1-\lambda_{r^{*}, r^{*}}\right) \sum_{i \in I} q_{i, f, r, l}\right. \\
& \left.-\sum_{g \in F_{r}}\left(1-\lambda_{r, r}\right) \sum_{i \in I} q_{i, g, r^{*}, l}-\eta_{r^{*}, r}\right) \\
& -\sum_{k \in K} \kappa_{k}\left(\sum_{l \in L} h_{l} \sum_{r \in R} \sum_{i \in I} \sum_{f \in F} \sigma_{i, r^{*}, k} q_{i, f, r, l}-E_{k}\right) .
\end{aligned}
$$

The optimal Karush-Kuhn-Tucker (KKT) conditions can be derived from (9) by taking the derivative with respect to the production of electricity $q_{i, f, r, l}$ for firm $f$ 
located in country $r^{*}\left(f \in F_{r^{*}}\right)$ :

$$
\begin{gathered}
\left(1-\lambda_{r^{*}, r}\right) p_{r, l}\left(S_{r, l}\right)\left[1-\xi_{f, l} \frac{\vartheta_{f, r, l}}{\varepsilon_{r, l}}\right] \\
-c_{i, r^{*}}^{\mathrm{v}}-\mu_{i, f, l}-\left(1-\lambda_{r^{*}, r^{*}}\right) \tau_{r^{*}, r, l} \\
-\sum_{k \in K} \kappa_{k} \sigma_{i, r^{*}, k} \geqslant 0 \perp 0 \leqslant q_{i, f, r, l} .
\end{gathered}
$$

Hence, as long as the marginal revenues from electricity sales are higher than the marginal costs of production, a power company is willing to produce electricity.

It is also possible to isolate the marginal costs from Eq. (10):

$$
c_{i, f, r, l}^{\mathrm{m}}=c_{i, r^{*}}^{\mathrm{v}}+\mu_{i, f, l}+\left(1-\lambda_{r^{*}, r^{*}}\right) \tau_{r^{*}, r, l}+\sum_{k \in K} \kappa_{k} \sigma_{i, r^{*}, k} .
$$

The four components of the marginal costs can also be interpreted economically. The first term on the righthand side in (11) shows the costs of producing electricity. The second and third term on the right-hand side in Eq. (11) are respectively the shadow prices of maximum production capacity per technology and the restrictions of trade. The fourth term on the left-hand side in Eq. (11) represents the addition to the production cost due to environmental constraints.

We have added a factor $\left(\xi_{f, l}\right)$ to the so-called market power mark-up $\left(\vartheta_{f, r, l} / \varepsilon_{r, l}\right)$ in Eq. (10) to make a distinction between price and quantity competition. If $\xi_{f, l}=0$, firms are competing in prices. This is the COMP case (perfect competition). If $\xi_{f, l}=1$, firms are competing in quantities. This is the STRA case (strategic competition). A value of $0 \leqslant \xi_{f, l} \leqslant 1$ can be assigned to derive a firm with an intermediary level of competition.

Summarising, the static model consists of 8 variables $\left(s_{f, r, l}, \quad p_{r, l}, \quad \vartheta_{f, r, l}, \quad x_{r, r^{*}, l}, \quad \mu_{i, f, l}, \quad \tau_{r, r^{*}, l}, \kappa_{k}, q_{i, f, r, l}\right)$ and 8 equations (times the indices), namely (2)-(8), (10). Firm behaviour can be determined by setting the market power mark-up scaling factor $\xi_{f, l}$ : $\operatorname{COMP}\left(\xi_{f, l}=0\right)$ and STRA $\left(\xi_{f, l}=1\right.$ for large firms, while $\xi_{f, l}=0$ for the fringes).

\section{References}

AKF, 1997. AKF, Energy Taxes and Subsidies in Denmark, www.akf.dk/eng/afgifter.htm.

Amundsen, E., Bergman, L., 2002. Will cross-ownership re-establish market power in the Nordic power market? The Energy Journal 23 (2), 73-95.

Andersson, B., 1997. Essays on the Swedish electricity market. Dissertation, Stockholm School of Economics, Stockholm.

Becker, G., Sun, W., Huang, J.O., 2004. Liberalisation of the European electricity market: who wins? Effects of mergers and emission trading on retail prices, company profit and pollution using the EMELIE model. Masters thesis, Faculty of Earth and Life Sciences, Free University, Amsterdam, The Netherlands.

Bigano, A., Proost, S., 2002. The opening of the European electricity market and environmental policy: does the degree of competition matter? Center for Economic Studies, Katholieke Universiteit Leuven. http://weber.ucsd.edu/ carsonvs/papers/602.pdf.

Boots, M.G., Rijkers, F.A.M., Hobbs, B.F., 2004. Trading in the Downstream European Gas Market: A Successive Oligopoly Approach. The Energy Journal 25 (3), 73-102.

Bower, J., Bunn, D.W., Wattendrup, C., 2001. A model-based analysis of strategic consolidation in the German electricity industry. Energy Policy 29, 987-1005.

Brubakk, L., Aaserud, M., Pellekaan, W., von Ostvoorn, F., 1995. SEEM - an energy demand model for Western Europe. Report 95/ 24, Statistics Norway, Oslo.

ECB, 2001. ECB Montly Bulletin January 2001, www.ecb.int.

EUL, 2002. Eurelectric, tax harmonisation in the electricity sector in the European Union in 2000. April, 2002, Ref: 2002-570-0006.

ExternE, 1999. Externalities of Energy, National Implementation, vol. 10. European Commission, Luxembourg.

Grohnheit, P.-E., 2003. Three modelling tools for analysis of competition on the power market of Denmark and northern Germany-EFOM, Balmorel, EMELIE. Risø National Laboratory, Systems Analysis Department.

Helman, U., Hobbs, J.B., Cardell, T., Luong, T., Wander, M.T., 1999. Modelling strategic pricing in bilateral and poolco electricity markets: a Nash-Cournot approach with applications to US eastern interconnection, INFORMS national meeting, Philadelphia, Npv. 7-10.

Hobbs, B.F., Rijkers, F.A.M., 2004a. Strategic generation with conjectured transmission price responses in a mixed transmission pricing system-Part I: formulation. IEEE Transactions on Power Systems 19 (2), 707-717.

Hobbs, B.F., Rijkers, F.A.M., 2004b. Strategic generation with conjectured transmission price responses in a mixed transmission pricing system-Part I: application. IEEE Transactions on Power Systems 19 (2), 872-879.

IEA, 2002. OECD/IEA Electricity Information 2002, Table 3, year 2000.

IEA, 2003. IEA/OECD, Energy Prices \& Taxes, Third Quarter 2003.

Jing-Yuan, W., Smeers, Y., 1999. Spatial oligopolistic electricity models with Cournot Generators and regulated transmission prices. Operations Research 47 (1), 102-112.

Kemfert, C., 1999. Liberalisation of the German electricity marketstrategies and opportunities. Nota di Lavoro, Milan, Italy, 95. 99.

Kemfert, C., Tol, R.S.J., 2000. The liberalisation of the German electricity market-modelling an oligopolistic structure by a computational game theoretic model. Working Paper 89/2000, Oldenburg.

Kemfert, C., Barbu, D., Kalshnikov, V., 2002. Economic impact assessment of the European electricity market. Working Paper, Oldenburg.

Koopmans, C.C., te Velde, D.W., Groot, W., Hendriks, J.H.A., 1999. NEMO: Netherlands energy demand MOdel a top-down model based on bottom-up information. CPB Research Memorandum (155), The Hague.

Lise, W., Linderhof, V., 2004. Electricity market liberalisation in Europe-Who's got the power? Internally reviewed report (R-04/ 03), Institute for Environmental Studies, Free University, Amsterdam, The Netherlands.

Lise, W., Kemfert, C., Tol, R.S.J., 2003. The German electricity market - does liberalisation bring competition? Nota di Lavoro, Milan, Italy, 3.03.

Murphy, F.H., Sherali, H.D., Soyster, A.L., 1982. A mathematical programming approach for determining ologopolistic market equilibrium. Mathematical Programming 24, 92-106.

Newbery, D.M., 2001. Economic reform in Europe: integrating and liberalizing the market for services. Utilities Policy 10, 85-97. 
Newbery, D.M., 2002. European deregulation, problems of liberalising the electricity industry. European Economic Review 46, 919-927.

Newbery, D., van Damme, E., von der Fehr, N.-H.M., 2003. Benelux market integration: Market power concerns. Office of Energy Regulation (DTe), The Hague, The Netherlands, http:// www.dte.nl/nl/Images/12_13216.pdf.

Pineau, P.O., Murto, P., 2003. An oligopolistic investment model of the Finnish electricity market. Annals of Operations Research 121, 123-148.

Salant, S.W., Shaffer, G., 1999. Unequal treatment of identical agents in Cournot Equilibrium. American Economic Review 89 (3), 585-604.
SE, 2000. Swedenergy, Elmarknades utveckling och struktur 2000 (Development and structure of the electricity market in 2000).

Sijm, J., 2004. The impact of the EU emissions trading scheme on the price of electricity in The Netherlands. Energy research Center Netherlands, Petten, The Netherlands, ECN-RX-04-015. 13 pp. http://www.ecn.nl/docs/library/report/2004/rx04015.pdf.

STEM, 2000. Swedish Energy Agency, Energiförsörjningen i Sverige: Korttidsprognos 2000-11-02 (Energy supply in Sweden: Short-time forecast 2000-11-02), www.stem.se.

Stern, J., 1998. Competition and liberalisation in the European gas market: a diversity of models, London. 